\title{
CORRECTION
}

View Article Online

View Journal I View Issue

D) Check for updates

Cite this: RSC Adv., 2021, 11, 17537

DOI: 10.1039/d1ra90110a

rsc.li/rsc-advances

\section{Correction: Integrated all-solid-state sulfite sensors modified with two different ion-to- electron transducers: rapid assessment of sulfite in beverages}

\author{
Hisham S. M. Abd-Rabboh, ${ }^{\text {ab }}$ Abd El-Galil E. Amr, ${ }^{\text {*cd }}$ Ayman H. Kamel, ${ }^{\text {*a }}$ \\ Mohamed A. Al-Omar' and Ahmed Y. A. Sayed ${ }^{c}$ \\ Correction for 'Integrated all-solid-state sulfite sensors modified with two different ion-to-electron \\ transducers: rapid assessment of sulfite in beverages' by Hisham S. M. Abd-Rabboh et al., RSC Adv., 2021, \\ 11, 3783-3791, DOI: 10.1039/D0RA09903A.
}

The authors regret that the affiliations for one of the co-authors (Mohamed A. Al-Omar) were incorrectly shown in the original article. The correct affiliations are given here.

The Royal Society of Chemistry apologises for these errors and any consequent inconvenience to authors and readers. 